\title{
A ROMANTIC TWENTIETH-CENTURY WELSH VIEW OF POLISH LiteratURE FROM 1800-1945
}

\author{
KAROLINA ROSIAK \\ SABINE HEINZ
}

\section{Synopsis ${ }^{1}$}

In the following, an example of the effects of limited research and printing recourses in Wales in the 1950s is given. Unlike in Ireland, which became an independent state in 1922, Wales has not even had an Assembly until 1997 to take responsibility of its own affairs, including its vernacular language and literature. ${ }^{2}$ As a result, whereas Ireland has been comprehensively promoting Irish-language writing as part of language planning since as early as 1920 (Ui Laighléis 2007), which eventually led to the foundation of the state-funded publishing house An Gúm, first institutional support for Welsh-language planning did not really start before 1961, when The Welsh Book Council was founded. As a consequence, publishing in Welsh was much due to private initiative. In a rather insufficient and random way, it was supported by a few grants available from the University of Wales in the 1950s which, first of all, focused on the promotion of popular material. It is in this context that we need to understand the following investigation.

\section{Introduction}

Despite approximately three hundred years of Polish emigration to the British Isles of which Wales is a constituent part, translations of Polish literature are rather scarce, in particular translations into Welsh. Even in the twentieth century, which saw various major waves of emigration to the UK, this situation did not change considerably. ${ }^{3}$

Translations of Polish authors into Welsh occurred predominantly in the 1970s and 1980s, but rather as individual publications than as projects which focused on Poland or the expression of an explicit interest towards its culture

\footnotetext{
${ }^{1}$ We would like to thank Siôn Williams and Dr Michael Hornsby for valuable comments.

${ }^{2}$ Even today, its law-making powers are still restricted to measures on devolved matters, see Government of Wales Act 2006 (http://www.ukcle.ac.uk/newsevents/lilac/2008/papers/wales.html).

${ }^{3}$ An emigration peak was reached most recently in 2007 (cf. Biuletyn Migracyjny 2007: 1) after major political and economic re-organisation in Europe in the last decade of the twentieth century. Part of it was due to the admission of Poland to the EU in 2004.
} 
(cf. Hudson-Williams 1953: 63). One of them presents a series of poems by Zbigniew Herbert (1924-1998), published in 1985 as part of a series of modern poets from the continent. Others are Storïau Byr o'r Bwyleg (1974) ${ }^{4}$ and a novel by Jerzy Andrzejewski (1909-1983), ${ }^{5}$ both of them translated by John Elwyn Jones.

In December 2008, Dr Eirug Davies of Boston brought Welsh translations of Polish literature to our attention. They were done by Thomas Hudson-Williams (1873-1961), a former Welsh lecturer in Greek, Latin, French and Celtic at the University College of Bangor and later Professor of Greek (1904-1940). He had translated classical works into Welsh and, after his retirement, started learning Russian. Having found out about literary connections between Alexander Sergeyevich Pushkin (1799-1837), a Romantic, one of the greatest Russian poets, and the founder of modern Russian literature, and Adam Mickiewicz (17981855), also a Romantic and one of the greatest Polish poets, he began his search for Polish literature and to learn to read Polish.

This happened at the outset of the second half of the last century, when various media developed higher levels of quality. As a result, many cultures and languages were introduced to the UK audiences, but not the Polish one, as was noted by Hudson-Williams (1953: 63). Thus he must have felt the need to introduce Polish literature, including very brief remarks on the language (ib., 11), the history of Poland (ib., 7-10) and its world of learning (ib., 11-19).

The following factors may also have been important to provoke his feelings. Firstly, although early Polish emigration to the British Isles, beginning in the seventeenth century, was rather limited, it intensified at the end of the eighteenth and during the nineteenth centuries, ${ }^{6}$ and increased significantly from 1920 onwards. $^{7}$ Secondly, Poles played an important role in the RAF during World War II. After the war, the number of Poles kept increasing, due to such factors as The Polish Resettlement Act of $1942^{8}$ and post-war re-locations of Poles and bordering ethnic groups as agreed in internationally recognised treaties, leading to an estimate of 162,000 Poles in 1951 in Great Britain (Biuletyn

\footnotetext{
${ }^{4}$ Stories from Bolesław Prus, so it is said. However, one of them is from Sienkiewicz, i.e. Latarnik.

${ }^{5}$ Lludw a diemwnt 'Popiół i Diament' (Ashes and Diamond) published in 1976.

${ }^{6}$ The eighteenth century witnessed 'The Three Partitions' $(1772,1793,1795)$ and resistance against them, e.g. Powstanie Kościuszkowskie 'Kosciuszko Uprising' in 1794 and the nineteenth century uprisings, e.g. Powstanie Listopadowe 'November Uprising' of 1830, Powstanie Styczniowe 'January Uprising' of 1863.

${ }^{7}$ Reasons for emigration included economic crisis and political oppression, e.g. the Nazi occupation (1939-1945), when for instance, the writers Jan Lechon (1899-1956) and Julian Tuwim (1894-1953) fled.

${ }^{8}$ This act allowed Polish soldiers to remain in the UK after World War II. As a consequence, a first emigration peak was reached between 1945 and 1948 (Biuletyn Migracyjny 2007: 2).
} 
Migracyjny 2007: 1). Thus, Poles formed major settlements in Wales in the 1950s, e.g. in Mid-West Wales, ${ }^{9}$ near and in Pwllheli ${ }^{10}$ and Y Bala.

Thirdly, Hudson-Williams may have seen interesting aspects of Polish literature. He thought they were worth popularising among genuine Welsh population which had experienced the arrival of large groups of people from this Slavic culture. As a result, he produced Bannau Llên Pwyl 'Highlights of Polish Literature' in 1953.

\section{Highlights of Polish literature according to Hudson-Williams}

\subsection{Yr Oes Aur}

Hudson-Williams, after an introductory section (1953: 7-18), provides more detailed information and commences with what he calls Oes Aur llenyddiaeth y Pwyliaid 'The Golden Age of the literature of the Poles' and starts with the poet Jan Kochanowski (1530-1584). He identifies two other major poets for this period, which he could also have termed Renaissance, i.e. Piotr Skarga Pawęnski (1536-1612) and Mikołaj Rej (1505-?1569). Whereas brief details about the lives and works of Kochanowski and Skarga are given, those of Rej can only be found in Hudson-Williams's (1953: 16) general introduction.

\subsection{0-1822}

The second period identified by the author spans 1700 to 1822. His analysis, however, lacks essential knowledge about Polish writers and their works at that time. The core information given is that Stanisław Konarski was active at that time and that a theatre was opened in Warsaw (ib., 32). No further data is provided, but three other authors are mentioned, i.e. Ignacy Krasicki (1735-1801), Stanisław Trembecki, and Józef Wybicki (Hudson-Williams 1953: 32, 34), again, with no further data.

\footnotetext{
${ }^{9}$ Llanon/Ceredigion, for instance, was a place for foreign residents after World War II, as we were kindly informed by Dr Eirug Davies of Boston. Firstly, a prisoner of war camp for Italians was established here on an old RAF place. They were later replaced initially by Germans (POW) and subsequently by Ukrainians, perhaps as a consequence of the uprising of Ukraińska Powstańcza Armia in Poland about 1947. Indeed, a Ukrainian, Andrej Zakharkiv (Андріи Захарків, born 1901) was interred there in 1948. In 1950, a recently arrived girl - Katarzyna Stawarz - was buried. Like other Poles, her parents had moved into the area and lived first in the old brewery, and then in newly-built cottages directly by the seaside. For further details on Polish graves, see Grabowska (2004).

${ }^{10}$ Near Pwllheli on the Llŷn Peninsula/Gwynedd, for instance, is Penrhos. There the farmhouse Penyberth, which had been the home to generations of poets' patrons, was destroyed by the UK government in 1936 in order to build a training camp and aerodrome for the RAF. As a result, Welsh nationalism was ignited and the bombing school was set on fire by the classic of the Welsh drama, Saunders Lewis (1893-1985), and two of his friends. The events surrounding the protest are known as Tân yn Llŷn 'Fire in Llŷn'.
} 


\subsection{Y Prifardd}

Instead of being characterised in the form of another time period, HudsonWilliams's third chapter is entitled 'Y Prifardd' (The Chief Bard), which is the title normally awarded to the winner of a literary Eisteddfod-competition, the major Welsh literary and cultural festival which was first attested in 1176 in Aberteifi. However, having read Pan Tadeusz himself (Hudson-Williams's 1953: 36), he finds Adam Mickiewicz, the author of this epic, worthy of this title. Nevertheless, he rather praises the verses than the author and devotes nearly a whole chapter on comparing Pan Tadeusz with other masterpieces of world literature, e.g. John Milton's (1608-1674) Paradise Lost, or Pushkin's Yevgyeniy Onyegin, a novel in verse, and says:

Mawr yw bri Pan Tadeusz ymhlith y Pwyliaid; hi yw eu "hepig genedlaethol"; ag eithrio cerddi Homer ni wn am unrhyw gerdd a lynodd mor ddwfn yng nghalon cenedl gyfan.

(Hudson-Williams 1953: 37)

Great is the prestige of Pan Tadeusz amongst the Poles. This is their 'national epic'. Apart from Homer's poems I do not know of any other poem which has stuck so deeply in the heart of a whole nation.

This time, Hudson-Williams also provides some comments on stylistic features. Having first complained that there is no rhyme in Polish literature before Mickiewicz, which he finds boring, he now comes to the conclusion that the language of Pan Tadeusz is not sublime, but the comparisons and metaphors are great. In addition, with rhyming patterns frequently changing emphasis and rhyme, Hudson-Williams finds Pan Tadeusz too complicated for a verse translation, so that he opts for a prose rendering. After having mentioned the influence of Pan Tadeusz on other works, e.g. on that of Władysław Reymont (1868-1925) and Franciszek Karpiński (1741-1825), he opens our eyes to some historical intricacies (Hudson-Williams's 1953: 39, 46), when he hints at the Lithuanian background of Mickiewicz. His solution in the end is a very Solomonian one: as Mickiewicz calls Lithuania his 'mother country' in the poem and describes its customs and national costumes, but calls Poland his 'mum' in the epilogue, Hudson-Williams supposes that the mother is closer to a person than the mother country. Consequently, he himself has no problem distinguishing between political (Lithuania) and cultural (or ethnical) matters (Poland).

\subsection{Dramâu'r Proffwydi}

Hudson-Williams's fourth exemplifying chapter mentions plays of the prophets 'Dramâu'r Proffwydi' and concentrates on the playwrights from the nineteenth century. The author notices the use of paganism and supernatural elements (ib., 63), experiments with metrical features $(i b ., 46)$ and the treatment of love for the 
country. These are all well known features of Romantic literature and often found in the sources of influence on Polish works of this time, for example, Lord Byron and Sir Walter Scott (Hudson-Williams's 1953: 48ff.). Polish playwrights and poets mentioned are Mickiewicz, Juliusz Słowacki (1809-1849), Zygmunt Krasiński (1812-1859), Józef Zaleski (1802-86; ib., 52), Kazimierz Brodziński (1791-1835), and Cyprian Kamil Norwid (1821-1883).

\subsection{Canrif o gerddi: pigion a'm denodd}

The fifth sub-chapter is entitled 'A century of poems: Selections which appealed to me'. ${ }^{11}$ What Hudson-Williams calls a century of poems lasts from 1812 to 1940 and therefore concentrates on Romantic literature again. Reading through most of the translations which are provided fragmentarily, it becomes clear that a Romantic view seems to suit the author and his Celtic background. ${ }^{12}$ Since The Celtic Renaissance - closely linked to W. B. Yeats (1865-1939) and his Celtic Twilight (1893) - parts of insular Celtic literature (and music) feature a melancholic mood, which often incorporates tradition and patriotism thus escaping undesirable reality. And this is exactly what is displayed in many of the Polish pieces which Hudson-Williams finds attractive.

The author is specifically fond of the apocalyptic element in Mickiewicz's Cân Yr Hynafiaid 'Dziady' ('The Forefathers') and by the Italian-type sonnet Cisza morska 'Quietness of the Sea' by Jan Kasprowicz (1860-19263). However, he translates the latter freely in content and style, entitling it Pan fo'r mor yn dawel 'When the Sea is Quiet'.

Zygmunt Krasiński's Cwyn y Bardd 'The Complaint of the Bard' recalls the fourteenth century Welsh poem 'A Minstrel's Boast' by Jocyn Ddu ( $c f$. Johnston 1991: 83) and Caru Chwerw 'Bitter Love', the complaint of a refused lover. An unwritten letter of a girl is the topic of Llythyr Merch 'The Letter of a Girl/Daughter' by Antonia Szczensna (1861-1930). Then Hudson-Williams presents six lines out of the sonnet cycle $Z$ Chalupy 'From the Cottage' by Jan Kasprowicz (1860-1926) which treats his childhood memories and gives them a new title, Hiraeth Alltud am y pentref 'The Longing of the Exile for the Village', thus changing the intended focus of the original work.

The poem Y Gawod Gyntaf ‘The First Shower’ by Zdzisław Dębicki (18711933) recalls spring descriptions as found, for instance, in the poem 'The Month of May' by Dafydd ap Gwilym. ${ }^{13}$ Siôn y Fynwent 'Janko Cmentarnik' (John the Graveyard) by Władysław Syrokomla (1822-1862) ${ }^{14}$ would appeal to a Welsh audience because it reflects Wales's nick-naming tradition ( $c f$. Jędrzejewska-

\footnotetext{
${ }^{11}$ In the table of contents he calls this chapter dyfyniadau 'quotations'.

${ }^{12}$ Romanticism in Wales lasted until Hedd Wyn (Ellis Humphrey Evans, 1887-1917), in Ireland until Yeats (1865-1939), and the last Polish Romantic was Krzysztof Kamil Baczyński (1921-1944).

${ }^{13}$ Cf. Mis Mai by Dafydd ap Gwilym (c. 1315/1320 - c. 1350/1370, Parry 1979: 67).

${ }^{14}$ Władysław Syrokomla was the pseudonym of Ludwik Władysław Franciszek Kondratowicz.
} 
Pyszczak 2009). Similarly acceptable for a Welsh audience are the lines entitled O Fynyddoedd Tatr 'From the Tatra Hills' by Kazimierz Przerwa-Tetmajer (1865-1940), since Wales is a country which uses hills and mountains as culturedefining features of landscape.

The poem A jak poszedt Król na wojnę... 'And When the King Went to War' by Maria Konopnicka (1846-1910) is simply represented by a few lines entitled Stach, the name of a poor person who dies on the battle field whereas the king goes back to his castle in good health. Changing the title shifts the emphasis of the poem to the pity of Stach instead of concentrating on the privileges and the morally inacceptable behaviour of the king.

The lines Oczy 'Eyes' out of Lucjan Rydel's (1870-1918) Romantic description of his wife entitled Mojej żonie is selected and given the title of the whole of the work, i.e. I'm wraig 'For My Wife'. Other poetic fragments difficult to assign to their original are Hiraeth 'Longing' taken from Rydel, featuring again the motif of the beloved village, Diddanwch yr Aelwyd 'The Comfort of the Hearth' taken from Przerwa-Tetmajer, and Cwynion ofer 'Wasted Womplaints' taken from Adam Asnyk (1830-1897).

\subsection{Nofelwyr}

In his sixth sub-chapter, Hudson-Williams states that novelists of the nineteenth century relied on old history and stories of the pagan world or expressed love of freedom, thinking of far away countries, or indulged in landscape and underpins his view with explanations on Henryk Sienkiewicz (1846-1925, HudsonWilliams's 1953: 64), who, according to the author, was the best known Polish writer of his time and awarded the Nobel prize in 1905 for his novel Quo vadis?. ${ }^{15}$ Others mentioned are Stefan Żeromski (1862-1925), Józef Weyssenhoff (1860-1932), Adolf Dygasiński (1839-1902), Eliza Orzeszkowa (1842-1010), Bolesław Prus (1847-1910), and W. S. Reymont (1868-1925), awarded Nobel Prize in 1924 for his four-volume novel Chtopi 'The Peasants'.

Hudson-Williams then chooses prose writings from 1846 to $1953 .{ }^{16}$ Works presented are Wiatr od Morza 'Gwynt o'r Môr' (The Wind from the Sea) by Stefan Żeromski, a master of Polish prose (ib., 65), and Latarnik 'Geidwad y Goleudy’ (The Lighthouse Keeper) by Henryk Sienkiewicz (ib., 68).

Confusion on the part of the reader is caused again, when Hudson-Williams then takes bits and pieces out of prose works and renames them, for example, Grunwald ar ôl y Frwydr 'Grunwald after the Battle' (1410) which comes out of the historic novel Krzyżacy 'The Teutonic Knights' and is set in medieval time. The other pieces taken from Sienkiewicz are Y Gwanwyn yn Podole 'Spring in

\footnotetext{
${ }^{15}$ Also, see Alan Titley's inspiring article in this volume on the Irish translation of the work. [eds.]

${ }^{16}$ As can be seen, he also includes some twentieth century pieces, therefore, slightly exceeding the preferred tendency towards Romanticism.
} 
Podole' (ib., 70), Częstochowa (ib., 69), the description of a town with a monastery and a miraculous picture of Maria, and the heroic sounding Syr Zagłoba yn cipio baner y gelyn 'Sir Zagłoba Snatches the Banner of the Enemy'.

A prose piece taken from W. S. Reymont is entitled Yn y bwthyn 'In the Cottage', the one chosen from Stanisław Witkiewicz (1851-1915) Yr Hydref ar fynyddoedd Tatr 'The Autumn in the Tatra Mountains' is perhaps from Pejzaz zimowy $w$ Tatrach 'Winter Landscape in the Tatra Mountains', depicting the motif of the mountains again. However, in case any potential Welsh readers were further interested in Polish literature and would have liked to read more from it, they would have had tremendous difficulties in finding out what to look for and how to get hold of the poems and prose works in question.

\subsection{Barddoniaeth rhwng y ddau ryfel mawr}

The sub-chapter on poetry between the two World Wars nourishes hopes that modern and modernist literary movements are now introduced. Hudson-Williams indeed mentions that after World War I, Polish literature was criticised for concentrating too much on country life and its praise (ib., 74), quite as it was true for much of Welsh literature at that time. However, mentioning new and modernist trends very briefly ( $i b ., 75)$, he gives only a few names, e.g. Kazimierz Wierzy[ń]ski (1894) and Jan Lechoń (ib., 75). ${ }^{17}$ In general, however, the interested reader has no chance to identify main representatives of major literary movements.

Hudson-Williams then shifts back to more Wales-familiar topics and presents, for instance, Julian Tuwim with Dwa wiatry 'Y Ddau Wynt' (The Two Winds). Surprisingly, this poem is given in full length and without an invented title, though with new paragraphing.

Next comes Kazimiera Iłłakowiczówna (1892-1983; ib., 78) with $Y$ Nos 'The Night' and Angau 'Death' (perhaps from Śmierć Feniksa), both featuring melancholy, bitterness, and isolation. Other fragments are from Leopold Staff (1878-1930) with Duw 'God', Maria Pawlikowska-Jasnorzewska (1891-1945) with Cân Serch 'Love Song', Antoni Słonimski (1895-1976) with Dau Haul 'Two Suns', and Jan Zahradnik (1904-29) Cân 'Song'.

\section{Comments on Hudson-Williams's findings}

The author says in the beginning, that he found the works of 179 poets and 822 poems (ib., 17). However, he refers to the source that we have not been able to identify, ${ }^{18}$ which formed the basis of his selection of pieces of Polish literature. Indeed, Hudson-Williams starts late in time, i.e. basically in the sixteenth century by introducing the first poets and a fragment of a lamentation (ib., 25). Having

\footnotetext{
${ }^{17}$ His proper name, Leszek Józef Serafinowicz, is not given.

${ }^{18}$ He speaks of $Y$ Flodeugerdd 'The Anthology' published in 1946 which is more than vague, even more so as a Polish book would not have had a Welsh title.
} 
left out the seventeenth century, the eighteenth and the early nineteenth centuries are depicted rather superficially, and sometimes lack such details as the correct or full names, the dating and other basic information. Nice surprises are, however, the chapter on Mickiewicz and his Pan Tadeusz and the chapter on playwriting, even more so as plays do not feature well in the Welsh literature before the nineteenth century. ${ }^{19}$

However, all further works selected seem to focus on what the target audience would supposedly like best. This is perhaps not the worst thing to do, if one wants to stir an interest in a foreign culture. Nevertheless, the way HudsonWilliams did this is rather problematic as illustrated in the following.

\subsection{Provision of data}

As a rule, there are nearly no Polish titles given, but mainly their Welsh translations only, except for Pan Tadeusz by Mickiewicz and Faraon and Emancypantki by Bolesław Prus (ib., 65). The names of the authors are respelled or otherwise incorrect and data in their regard is often incomplete, e.g. a 'Joseff Wybicki' should be correctly read as 'Józef Wybicki' (1747-1822); 'Dygasinski' should be spelled as Adolf Dygasiński (1839-1915) etc. The principle of presenting the names of the Polish authors is not revealed and we cannot deduce that Hudson-Williams generally intended to respell the names, like Czenstochowa (which should be 'Częstochowa'), as some of them are kept in their proper Polish version, e.g. Kraków. To assume that specific fonts were unavailable at the time would be an understatement as they were visibly available at least sometimes ( $c f$. Kraków).

In addition, as has been previously shown, Hudson-Williams picked up random individual lines of the pieces to invent them a title, thus convincing a potential reader that this title is the original one of the respective poem or the prose piece. This approach makes it nearly impossible to search for the original work, even more so as any bibliographical or reference data is missing. Furthermore, no indication is given whether such 'selection' refers to (a) the choice made from a corpus of literary works, or (b) the selection of lines out of them, or (c) their new arrangement, or (d) the selection of freely invented titles. Such method has an even stronger impact on the literature presented, as it changes the intended focus of the original author.

Considering the presentation of Polish titles in Welsh, plus a dominating ignorance of Polish letters, the specific character of Poland's literature is hidden rather than promoted. This trend is strengthened by rendering the Polish protagonist 'Janko' from Janko Cmentarnik (Hudson-Williams 1953: 58) as 'Siôn’ or by presenting a ‘Guto’ (ib., 57). Every Welsh reader would be surprised

\footnotetext{
${ }^{19}$ Apart from few exceptions, Welsh drama does not develop before the eighteenth-nineteenth centuries ( $c f$. Heinz 2007: 60).
} 
to read of famous Welsh names in Polish poems. And, of course, the endearment of 'Janko' is omitted in the Welsh 'Siôn', although Welsh has means of expressing this concept synthetically and analytically (cf. Heinz 2004, 2009, Rosiak 2009).

In addition, being confined by a specific Welsh perspective, HudsonWilliams consequently complains about the lack of what would be the Welsh rhymes and metrics instead of looking for some specific Polish stylistic features.

\subsection{Comparing cultures}

As Hudson-Williams seems to like similarities between Welsh and Polish cultural traditions, he also makes a comparison between nicknaming in Poland and in Wales (ib., 44). However, nicknaming in Wales is much more prominent than in Poland (cf. Jędrzejewska-Pyszczak 2009, 2010), where diminutive formations partly take over its function, in particular when it is to express endearment. In addition, the popularity of nicknaming in Wales is further promoted by its colonial heritage ( $c f$. Jędrzejewska-Pyszczak 2009: 52ff.), which left the country with a reduced variety of dominating surnames, as, for instance, the surnames Jones or Davies, in so far as the identification of individuals is impaired. ${ }^{20}$ This phenomenon is not known to Poland to such a degree and is rather restricted to the first names with surnames attached for clear identification.

As we have already mentioned, the choice of topics in Hudson-Williams is broadly orientated on what would appeal to the Welsh target audience, e.g. the motif of the village, nature descriptions, melancholic mood, local politics ( $c f$. a change of focus to Stach). This may be the reason why the nationalistic and messianic Księgi narodu polskiego i pielgrzymstwa polskiego 'The Books of the Polish Nation and Its Pilgrimage' (1832) by Mickiewicz are not chosen for the translation. However, a reference to them could have been expected, even more so as such translation had been already available in a cognate Celtic language, i.e. in Irish by Ó Rinn (1920).

\section{Conclusion}

Despite the long history of Polish emigration to the British Isles, little or nothing appears to be known about Polish literature there. Hudson-Williams may be superficial in aspects, but seems to provide the only major overview of the field. However, despite the many Poles in Gwynedd at his time, he did not go directly for Polish literature, but discovered it through the Russian Romantic Pushkin and managed largely to ignore the present-day Polish literature. Hudson-Williams remains entrenched in Romanticism, although modern and modernist literature had been well developed at his time. Movements, such as Young Poland (1890-

\footnotetext{
${ }^{20}$ Often the first names are also similar, so that the following names are frequently heard: Bryn Jones, Tom Jones, Siôn Williams, Hywel Davies, (G)Wyn Thomas etc.
} 
1918), are not even mentioned, although some of its neo-Romantic representatives, e.g. Żeromski, Reymont and Wypiański, are presented. More about them or Baczyński would have served the author's major focus well. The latter would have suited a comparative view, as he was a Romantic killed in war, just like the Welshman Hedd Wyn. However, Baczyński died in World War II and Hedd Wyn in World War I.

Another comparison could have been made between Reymont and Kate Roberts (1891-1985) as both introduced the industrial novel to their cultures; however, Reymont was a representative of the modernist movement and Roberts was an adherent to realism.

Altogether, the work that is called 'The Highlights of the Polish Literature' and which promised to be a nice surprise and an urgently needed book at the time, turned out to be a disappointment, focusing predominantly on the Romantic Polish literature. Although the author inadvertently refers to other books of Polish literature and provides citations from them (e.g. see Chrzanowski referred to at page 6 therein) or Wojciechowski (no reference provided) he presents an introductory work which is rather insufficient in its content and objective character and superficial in its understanding and comparing of different cultures ( $c f$. such details as the naming patterns etc., the metrical features, the correctness of data). As a consequence, foreign elements are suppressed, so that an impression of the other culture is limited. The topics chosen, the language presented, all tend to disguise rather than reveal that the literature presented is a Slavic one.

Hudson-Williams's inadequacies are nevertheless rather surprising. He was an experienced scholar and the register of the Welsh language he used in his work indicates that this book was not intended for popular reading. But, perhaps, discovering a culture in a rather second-hand manner accounts for the problems outlined here.

However, similar features of insufficiency can be attributed to the translations by John Elwyn Jones (d. 2007). He, first of all, confuses authors and includes in a volume of Polish short stories by Prus one by Sienkiewicz. In addition, his spelling of Polish names is inconsistent and occasionally erroneous, as seen in such examples as 'Bolestaw Pruss' and 'Laternik' [sic], although this translator was in Poland as a prisoner of war.

To conclude, the anthology was written by a well-established academic and published by Gwasg Aberystwyth (1930s-1960s), well-known for its good popular and academic books in the fields of Welsh literature and culture, and occasionally in linguistics, an example being Geiriadur Mawr. As a consequence, a good popular or academic work could have been expected. However, Slavic languages have never formed a major subject in Welsh academia which itself had not properly developed before the beginning of the twentieth century. As a consequence, a retired academic tried to fill in a cultural gap which he realised 
when he saw all the Polish immigrants in Wales. However, he did not succeed in scrutinising and subsequently presenting Polish literature in a satisfactory way. As a consequence, his book remains an example of minority publishing in any sense and with all its implications. Considering the insufficiencies and the entirely subjective basis of the selection of Polish literary works and their presentation, a more objective, up-dated work aimed at featuring culture-specific aspects of Polish literature remains to be written.

Adam Mickiewicz University, Poznań, Poland

\section{References}

Chrzanowski, I., 1974, Historia literatury niepodlegtej Polski, Warszawa: Państwowy Instytut Wydawniczy.

Grabowska, K., 2004, Polskie Groby na cmentarzach Pólnocnej Walii, Kraków: Polska Akademia Umiejetnosci.

Heinz, S., 2004, 'The Diminutive in the Modern Welsh language', in: Celtic Forum 4/5, 10-7.

Heinz, S., 2007, Celtic Literatures - Discoveries, Berlin: Peter-Lang Verlag.

Heinz, S., 2009, 'Diminutive Formations in Modern Welsh and Functions of Their Formants', in: M. Bloch-Trojnar, ed., Perspectives on Celtic Languages, Lublin Series in Celtic Linguistics 6, Lublin: Wydawnictwo KUL, 187-198.

Herbert, Z., 1985, Zbigniew Herbert: Detholiad o’i gerddi, Caerdydd: Gwasg Prifysgol Cymru.

Hudson-Williams, T., 1953, Bannau Llên Pwyl, Aberystwyth: Gwasg Aberystwyth.

Jędrzejewska-Pyszczak, K., 2009, The Use of Pseudonyms and Nicknames in the British Isles with Emphasis on Wales, https://ifa.amu.edu.pl/phdthesis/ users.php, 25.10.2009.

Jędrzejewska-Pyszczak, K., 2010, 'Syntactic Patterns in Welsh and English Nicknames - a Comparison', in: Stalmaszczyk, P. \& Fomin, M., eds., Dimensions and Categories of Celticity: Studies in Language. Proceedings of the Fourth International Colloquium of Societas CeltoSlavica held at the University of Lódź, Poland, 13-15 September 2009. Part 1. Studia Celto-Slavica 4, Łódź: Łódź University Press, 115-124.

Johnston, D., ed., transl., 1991, Canu Maswedd yr Oesoedd Canol, Bridgend: Seren.

Jones, J. E., ed., transl., 1974, Storïau Byr o'r Bwyleg, Y Bala: Llyfrau'r Faner.

Jones, J. E., ed., transl., 1976, Lludw a diemwnt [Popiót i Diament], Llandysul: Gomer. 
Ó Rinn, L., 1920, Leabhar na Polainne, Dublin: An Comhlucht Éireannach um Thráchtáil Eadarnáisiúnta.

Parry, T., ed., transl., 1979, Gwaith Dafydd ap Gwilym, Caerdydd: Gwasg Prifysgol Cymru.

Rosiak, K., 2009, 'The Use of Diminutives by Speakers of Welsh', in: M. BlochTrojnar, ed., Perspectives on Celtic Languages, Lublin Series in Celtic Linguistics 6, Lublin: Wydawnictwo KUL, 237-247.

Uí Laighléis, G., 2007, ‘An Gúm: The Early Years’, in: Mac Mathúna, S. \& A. Ó Corráin, eds., M. Fomin, assistant ed., Celtic Literatures in the Twentieth Century, Moscow: Languages of Slavonic Culture, 199-216.

\section{Web references}

Biuletyn Migracyjny 4/5 2007: http://www.migracje.uw.edu.pl., 25.10.2009. Government of Wales Act 2006: http://www.ukcle.ac.uk/newsevents/lilac/2008/ papers/wales.html, 20.02.2010. 